\title{
Structure and succession dynamics of a Neotropical freshwater periphyton community, with emphasis on ciliates and their association with bacterial taxa
}

\section{Adriana Giongo}

Pontifícia Universidade Católica do Rio Grande do Sul, Instituto do Petróleo e dos Recursos Naturais

Luiz Gustavo dos Anjos Borges

Institute for Epidemiology and Pathogen Diagnostics

Taiz L. Lopes Simão

Pontifícia Universidade Católica do Rio Grande do Sul

\section{Eduardo Eizirik}

Pontifícia Universidade Católica do Rio Grande do Sul

Laura Utz ( $\square$ laura.utz@pucrs.br)

Pontificia Universidade Catolica do Rio Grande do Sul https://orcid.org/0000-0002-4343-4672

\section{Research Article}

Keywords: biofilm, e-DNA, lake, Ciliophora, Peritrichia

Posted Date: January 14th, 2022

DOI: https://doi.org/10.21203/rs.3.rs-1247788/v1

License: (c) (i) This work is licensed under a Creative Commons Attribution 4.0 International License. Read Full License 


\section{Abstract}

Periphyton communities in freshwater systems play an essential role in biogeochemical processes, but knowledge of their structure and dynamics lags far behind other environments. We used eDNA metabarcoding of 16S and 18S rRNA markers to investigate the formation and establishment of a periphytic community, in addition to morphologybased analyses of its most abundant group (peritrich ciliates). We sampled two nearby sites within a large Neotropical lake at four time points, aiming to assess whether periphyton establishment can be replicated on this local scale. Producers and denitrifiers were abundant in the community, illustrating the relevant role of biofilms in freshwater nutrient recycling. Among microeukaryotes, peritrich ciliates dominated the community, with genera Epistylis and Vorticella being the most abundant and showing a clear succession at both sites. Other ciliates were identified and, in some cases, their occurrence was strongly related to bacterial abundance. The structure and succession dynamics of both prokaryotic and eukaryotic components of periphyton differed between the two sites, in spite of their adjacent locations and similar abiotic properties, indicating that the establishment of these communities can vary even on a local scale within a lake ecosystem.

\section{Introduction}

Periphyton or biofilms in freshwater systems are complex communities of prokaryotes, algae, protozoa, fungi and small metazoans that live on submerged surfaces [1]. Such communities can represent a significant portion of the bacterial biomass in natural and artificial environments [2]. Accordingly, it is estimated that periphytic production could contribute to over $80 \%$ of the primary production in some lakes [3]. Moreover, periphyton plays an essential role in biogeochemical processes such as nitrification, denitrification, and nutrient cycling, including mercury methylation and hydrogen sulfide production [4]. Despite their ecological relevance, knowledge about the structure and dynamics of these communities, including the interactions among their component microorganisms and their role in food webs, lags far behind other aquatic environments [5].

A wide range of prokaryotes and eukaryotes are essential components of the periphyton, although the factors driving its species richness variation remain incompletely understood [6]. Among eukaryotic microorganisms in periphytic communities, the most abundant are sessile and free-living ciliates [7]. Ciliates, in general, participate in a broad range of metabolic pathways, selectively preying on bacteria as well as on small eukaryotes, and play a leading role in nutrient recycling that supports the trophic cascade in aquatic environments [5]. Several studies have pointed out ciliates as a major group in marine and freshwater periphytic communities. For example, 29 species of periphytic ciliates were identified and their occurrence correlated with water quality in a coastal area of Korea [8]. Mieczan [9] investigated the periphytic community in lakes dominated by phytoplankton or macrophytes and observed that ciliates were a major component of periphyton. Sikder et al. [10] investigated the composition of periphyton at different depths in a bay near Qingdao (China) and observed 92 ciliate species and a high degree of community succession.

Within ciliates, the subclass Peritrichia comprises sessile species that colonize both living and non-living substrates [11] and tend to be a major component of periphytic communities. Several studies have shown that peritrich ciliates are often dominant in freshwater periphyton, regardless of whether the community was sampled using artificial surfaces [10, 12] or living substrates [9].

Most studies on periphyton diversity have been conducted using morphology-based species identification, which limits the ability to characterize these communities as a whole. A more comprehensive assessment of their composition can be achieved with molecular approaches such as environmental DNA (eDNA) metabarcoding, which 
allows a standardized survey of all taxonomic groups present in a sample [13]. In addition, eDNA metabarcoding is also efficient at retrieving sequences from low-abundance taxa, allowing them to be included more effectively in community composition studies. Despite its power, few studies have used eDNA metabarcoding to characterize periphyton communities in marine or freshwater environments [14-17]. None of these studies was conducted in the Neotropics, highlighting the lack of information on these aquatic communities in this highly biodiverse region. Moreover, previous studies have focused mainly on the bacterial or algal components of periphyton, without exploring other groups that may play critical roles in the dynamics of these communities.

To address these issues, in the present study we employed ribosomal DNA amplicon sequencing to investigate the formation and establishment of the periphytic community of a large Neotropical lake. Given the critical role of peritrich ciliates in periphyton dynamics, we focused particular attention on this group by combining morphological and molecular data to characterize their species composition and succession process as this community is assembled.

\section{Material And Methods}

\section{Study area, experimental design, and sampling}

The study was conducted in Guaíba lake, Porto Alegre municipality, Rio Grande do Sul state, southernmost Brazil. The lake has a surface area of $496 \mathrm{~km}^{2}$ and a length of approximately $50 \mathrm{~km}$, ranging in width from 0.9 to $19 \mathrm{~km}$. Its average depth is $2 \mathrm{~m}$, reaching $12 \mathrm{~m}$ in the navigation channel [18]. The lake is used for water supply, irrigation, fishing, recreation and shipping. Large amounts of domestic, agricultural, and industrial wastewater are drained into the lake, compromising its water quality [19].

We sampled periphyton communities in 2012 at two nearby (ca. $3.5 \mathrm{~km}$ apart) locations within Guaíba

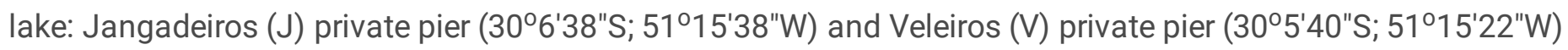

(Figure 1). These two sites were expected to have similar ecological features, despite differences in the water current [20]. Jangadeiros receives inputs from the predominant north-to-south flow direction, while Veleiros is more sheltered and thus less affected by this water current. By sampling these two sites, we aimed at assessing whether periphyton structure and succession dynamics can be replicated on this local scale within this broad lake system.

To sample periphyton, we used paired glass microscope slides pressed against each other, suspended from a buoyant device at a depth of $10 \mathrm{~cm}$ below the waterline. We set 12 pairs of slides at each sampling site, comprising four sampling units (each of which was retrieved at a different time point) containing three pairs each. We identified the time-based sampling units as T1, T2, T3, and T4 (see Table 1). At each time point, three slide pairs from each site were removed from the water, placed in a jar with lake water, and taken to the laboratory. Water was collected simultaneously as the glass slides. Temperature, $\mathrm{pH}$, and conductivity measurements were performed in the field. The Research Center of the Municipal Department of Water and Sewage (DMAE) provided total solids and dissolved oxygen values. Their collections were performed monthly in the vicinity of the sampled sites.

One member of each slide pair had its attached periphyton scraped with a scalpel into a microcentrifuge tube containing $1 \mathrm{~mL}$ of TES lysis buffer (1 mM Tris, $1 \mathrm{mM}$ EDTA, 2\% SDS) to undergo eDNA metabarcoding (see below). The other member was analyzed morphologically, focusing on peritrich ciliates, using a CH30 RF100 Olympus light microscope. Since peritrichs could colonize the whole slide, we placed a glass coverslip $(22 \times 22 \mathrm{~mm})$ in its center to delimit the analyzed area, in which we counted the total number of peritrich colonies or single zooids. Species abundance was calculated using the mean of the three replicates analyzed at each time point. Genera and species 
were identified using specialized literature. Photomicrographs of representative microorganisms were taken from live specimens using a digital camera mounted onto an optical Olympus BX50 microscope.

\section{DNA extraction and amplicon sequencing}

Total DNA was extracted from a $250-\mu \mathrm{L}$ aliquot of the TES-preserved sample using the DNeasy UltraClean Microbial Kit (Qiagen) following the manufacturer's instructions. The V4 region of the 16S rRNA gene was amplified using universal primers 515F and 806R [21]. Amplification was performed in a 50- $\mu \mathrm{L}$ reaction, containing $2 \mathrm{mM}$ $\mathrm{MgCl}_{2}, 2 \mu \mathrm{M}$ of each primer, $2 \mathrm{mM}$ of each dNTP, $1 U$ Platinum Taq DNA polymerase, 1X PCR reaction buffer, and approximately $10 \mathrm{ng}$ of genomic DNA. PCR cycling conditions comprised one initial denaturation step at $95^{\circ} \mathrm{C}$ for 3 min, 35 cycles including denaturation for $30 \mathrm{~s}$ at $95^{\circ} \mathrm{C}$, annealing for $1 \mathrm{~min}$ at $50^{\circ} \mathrm{C}$, and extension for $1 \mathrm{~min}$ at $72^{\circ} \mathrm{C}$, and one final extension step for $7 \mathrm{~min}$ at $72^{\circ} \mathrm{C}$. For eukaryotic identification, a fragment of the 18S rRNA gene was amplified using primers Fw and Rv [22]. The PCR was also performed in a 50- $\mu \mathrm{L}$ reaction using the same conditions described above, with one initial cycle of denaturation at $94^{\circ} \mathrm{C}$ for $4 \mathrm{~min}, 30$ cycles including denaturation for $45 \mathrm{~s}$ at $94^{\circ} \mathrm{C}$, annealing for $30 \mathrm{~s}$ at $50^{\circ} \mathrm{C}$, and extension for $1 \mathrm{~min}$ at $72^{\circ} \mathrm{C}$, followed by one cycle of final extension of $7 \mathrm{~min}$ at $72^{\circ} \mathrm{C}$. Negative controls were included for the extraction and PCR amplification procedures. PCR amplicons were purified using the Agencourt AMPure Beads kit (Beckman Coulter), and libraries were constructed using the lon Plus Fragment Library kit (Thermo Fisher) from an initial amount of 100 ng of DNA. Since all samples were sequenced in a multiplexed run, barcode sequences were used to identify each sample from the total sequencing output. Sequencing was conducted on an Ion PGM System (Thermo Fisher) using an lon 316 chip, following the manufacturer's instructions. Sequencing results were deposited in the National Center for Biotechnology Information (NCBI) under BioProject PRJNA736224.

\section{DNA metabarcoding data analyses}

Sequences were processed and classified using the DADA2 (Divisive Amplicon Denoising Algorithm) v.1.12.1 pipeline [23] in R. Quality-trimming and filtering steps were performed using the "FilterAndTrimmed" function. Reads shorter than 100 bp were removed, and a maximum of 2 expected errors per read was allowed. The subsequent steps included error inference, denoising and chimera removal (Table S1). Amplicon sequence variants (ASVs) were taxonomically assigned using the SILVA database v. 138 [24]. ASVs belonging to Ciliophora were manually curated at genus level with a Megablast nucleotide search against the NCBI non-redundant nucleotide database. Sequences with $>97 \%$ identity to a known taxon were considered a potential match. When more than one taxon was retrieved above this threshold, the one with the highest identity and lowest e-value was considered the most likely match.

The microbial composition of samples was assessed after transformation to relative abundance. Heatmaps were constructed using phyloseq in R. Venn diagrams were built using the VennDiagram [25] in R. Alpha- and Betadiversity were assessed for bacterial ASVs using the phyloseq, vegan, and microbiome packages [26-28] in R. Bacterial sequences were rarefied considering the lowest number of sequences identified among all samples. Shannon and Chao1 biological diversity indices and Pielou's evenness index were tested using the Kruskal-Wallis and Wilcoxon Pairwise tests. Beta-diversity (based on square-root transformed ASV count data) was assessed with a Bray-Curtis dissimilarity index followed by a Multidimensional scaling (MDS) analysis. Permutation analysis of variance (Permanova) with 10,000 permutations was used to assess the statistical significance of these comparisons. Finally, we performed a Spearman correlation analysis between the abundance levels of bacteria and ciliates, with significance inferred when $p<0.05$, using an ANOVA with a false discovery rate (FDR) correction. 


\section{Results}

\section{Physical-chemical parameters}

Most water quality parameters showed no statistically significant differences between the two sampling sites. Water temperature (which ranged from $11^{\circ} \mathrm{C}$ to $18^{\circ} \mathrm{C}$ throughout the study) was the only parameter that was significantly different $(p=0.0052)$ between the sampling sites, being higher in Veleiros (Table 1).

\section{Periphytic bacterial community}

The bacterial diversity (Shannon; $p=0.52$ ), richness (Chao1; $p=0.11$ ), and evenness (Pielou; $p=0.95$ ) indices were not significantly different between the two sites (Figure 2A). The same was observed when the indices were used to assess the diversity of the community across the time points, except for evenness. After the initial formation of a microbial biofilm (T1), the periphytic community changed, and a significant difference was observed in evenness between T1 and T2 and remained significantly different until T4 (Pielou; $p=0.027$ ).

A MDS analysis was performed for both sampling sites (Figure 2B). The distance between groups was assessed for the variable time (Permanova; $\mathrm{R} 2=0.19 ; p=8.9 \times 10^{\wedge}-4$ ), and for the variable site (Permanova; $\mathrm{R} 2=0.12 ; p=$ $\left.9.9 \times 10^{\wedge}-5\right)$. For Jangadeiros, the bacterial periphytic community presented a more similar composition in $\mathrm{T} 1$, $\mathrm{T} 2$, and T3, differing from T4. Surprisingly, in Veleiros, T1, T2, and T4 clustered together and T3 was more dissimilar to the other time points. This implies that, in Veleiros, a disturbance of periphytic succession occurred between T2 and T3, and then the bacterial composition was re-established at T4. These observations are also discerned in the Venn diagrams. The periphytic succession in Jangadeiros includes an increase in the number of taxa commonly present in T1 to T3 (T1-T2, n = 72 and T1-T3, n = 89), but this is strongly reduced between T1 and T4 ( $\mathrm{n}=53$ ) (Figure 2C). In Veleiros, the number of common bacterial taxa at T1 and T2 $(n=56)$ was reduced at T3 $(n=36)$, but at T4 ( $=50)$ it returned to a similar level relative to the initial stage of the bacterial succession (Figure 2D).

A total of 28 bacterial phyla were identified during the study at the two sites. Of these, 11 presented a relative abundance higher than $1 \%$ at one or more sampling times. Proteobacteria dominated both sampling sites, with abundances ranging from $62.1 \%$ to $77.3 \%$ of the total community (Table S2). Bacteroidota was the second most abundant at both sites, followed by Nitrospira and Cyanobacteria. Acidobacteriota, Actinobacteriota, and Planctomycetota were also present at abundances higher than $1 \%$, with Planctomycetota presenting an abundance higher than $6 \%$ at T4 in Veleiros.

Among the most abundant ASVs in Jangadeiros, Citrobacter, a gram-negative coliform bacteria from the family Enterobacteriaceae, was the most abundant genus at T1 (up to $43 \%$ of the total sequences), disappearing at the other time points (Figure 3A; Table S3). In Veleiros, Serratia, a gram-negative coliform (Figure 3B; Table S3), was highly abundant at T1 (up to $44 \%$ of the total sequences), along with Pseudomonas, which appeared mainly at the first time point. Nitrosomonas, Candidatus Nitrotoga, Nitrosospira, and Flavobacterium were constantly present at the four time points.

\section{Periphytic eukaryotic communities}

Among eukaryotes, the most abundant group found at both sites was Alveolata, followed by "Excavates", Diatomea, and other Stramenopila (Figure 4A). Chlorophyta showed peaks of high abundance in Veleiros, but the same pattern was not observed in Jangadeiros. Ciliophora was the most abundant group within the Alveolata at both sites, representing more than $75 \%$ of the sequences, followed by Dinoflagellata, with up to $25 \%$ relative abundance (Figure 
4B). A Venn diagram of the distribution of Ciliophora taxa at different time points in Jangadeiros revealed that T1 harbored three unique taxa, while T2 and T3 presented five, and T4 had four unique taxa (Figure 4C; Table S4). In Veleiros, T1 harbored only two unique taxa, while T2, T3, and T4 harbor six, one, and four, respectively (Figure 4D; Table S4).

Among ciliates, the periphytic community at both sites was primarily composed of peritrichs, with the colonial genus Epistylis being the most abundant taxon (Figure 4E). Its highest relative abundance was observed at T2 in Jangadeiros and at T1, T3, and T4 in Veleiros. The genera Vorticella and Zoothamnium also exhibited high abundance. Vorticella reached a peak in Jangadeiros at T3, while Zoothamnium had its highest abundance in Veleiros at T2. Other peritrich genera were also present in the community, but at low abundance at both sites.

With regard to other ciliate genera, the heterotrich Stentor had a high relative abundance at T4 in Jangadeiros, but in Veleiros it was present at very low abundance along the microbial succession. Among predators, Amphileptus had an abundance of up to $12 \%$ at T1 in Jangadeiros. In Veleiros, the same genus showed a slightly lower abundance at T3 and T4 (Figure 4E).

\section{Correlation between bacterial and ciliate communities}

Spearman's correlation between Ciliophora and Bacteria taxa performed at genus level (or corresponding annotation) demonstrated potential ecological relationships among these groups along the periphytic microbial succession. A larger number of significant correlations was found in Jangadeiros compared to Veleiros (Figure 5). In Jangadeiros, genera associated with methanotrophy and methylotrophy, along with the nitrite-oxidase Nitrospira, presented significant correlations with ciliates. Considering the Ciliophora community, five genera showed positive correlations with a broad range of bacterial taxa (Figure 5A). In Veleiros, the methane oxidizer Crenothrix presented a positive correlation with three ciliate genera, and no negative correlations were observed at this site (Figure 5B).

\section{Ciliate morphology-based analyses}

The peritrich ciliate assemblage was composed of seven genera and nine morphologically identified species. All genera and species were recorded at both sites, except for Mioschiston duplicatum and Vaginicola tincta, recorded only in Jangadeiros (Figure 6). Epistylis was the most abundant peritrich genus in Jangadeiros at T1, with $E$. portoalegrensis reaching a peak of abundance, followed by E. smalli and E. plicatilis (Figure 6A). In Veleiros at T1, the most abundant genus was Vorticella, with $V$. convalaria reaching a high peak of abundance (Figure 6B).

At T2 in Jangadeiros, different species of Epistylis were still abundant, but Vorticella spp. showed an increase in abundance, reaching more than 1.000 inds $/ \mathrm{mm}^{2}$ (Table S5). A similar situation was observed at T2 in Veleiros, where Vorticella represented more than $45 \%$ of the peritrichs present in the samples (Figure $6 \mathrm{~A}$ ). At T3, both sites presented a dominance of genus Vorticella. Jangadeiros had a low abundance of peritrichs at T3, with Vorticella reaching an abundance of $150 \mathrm{inds} / \mathrm{mm}^{2}$. In Veleiros, the highest abundance of peritrichs during the study was observed at T3, with Vorticella reaching more than $90 \%$ of the peritrich records observed in the samples.

The lowest abundance of peritrichs in Jangadeiros was observed at T4. Species of Vorticella accounted for more than $80 \%$ of the peritrichs observed in the samples. In Veleiros at T4, a similar result was observed for Vorticella, with other genera presenting very low abundances (Figure 6A).

\section{Discussion}


Biofilm communities have been explored in several freshwater environments due to their importance in aquatic food webs $[5,29]$ and potential as water quality indicators [7]. To better understand the dynamics of periphytic communities, it is important to analyze the bacterial and microeukaryotic components jointly, since together they participate in production and recycling processes [30]. In this study, the bacterial and ciliate communities and their dynamics at two nearby sites in a lake in southern Brazil were explored using eDNA metabarcoding. Direct morphological identification was also applied to Peritrichia, the most abundant ciliate group during the surveyed period. To our knowledge, this is the first molecular study to analyze bacteria and microeukaryotes in biofilms of a lake ecosystem, and the first molecular survey of periphyton in Neotropical environments. We observed that, although our two sampling sites were adjacent within a larger lake and quite similar in terms of their abiotic properties, their periphyton composition and succession processes presented detectable differences.

With respect to functional assessments, it has been reported that most bacteria found in stream and river biofilms and revealed by amplicon sequencing belong to the phyla Proteobacteria, Bacteroidetes, Acidobacteria, Verrucomicrobia, and Cyanobacteria [30,31]. Proteobacteria was the dominant phylum in Veleiros and Jangadeiros during the periphytic succession. The peaks of high abundance of Proteobacteria at T1 observed for both sites are probably related to these bacteria's ability to first colonize rigid substrates. Moreover, sewage input contributes to this high abundance of enterobacteria since genera such as Salmonella, Klebsiella, and Enterobacter, all associated with humans, were present in the samples. Other studies have reported the presence of enterobacteria in the periphyton, suggesting that these communities could act as reservoirs of these bacteria [36].

Primary producers are generally abundant in bacterial periphytic communities. Cyanobacteria, for example, have been reported as the most abundant group in several studies. Zancarini et al. [30] found Cyanobacteria as the second most abundant group of prokaryotes in a river in France, in addition to diatoms and chlorophytes. In marine environments, Cyanobacteria have also been reported as highly abundant in communities sampled at the Great Barrier Reef [37]. In Guaíba lake, Cyanobacteria were present at both sampling sites at moderate abundances, probably having an important role in the primary production of the periphytic community.

The role of periphyton in nutrient cycling in different environments has been a focus of growing attention. Studies have demonstrated that periphytic communities can accelerate nutrient removal from the water column [38], enhance denitrification processes, and participate in methanogenesis [14]. In Guaíba lake, bacteria involved in nitrogen fixation (Rhizobiaceae taxa) and nitrite oxidation (Nitrosomonas and Nitrospira) were present at high abundance along the periphytic succession in Jangadeiros. On the other hand, the genera Nitrosomonas and Candidatus Nitrotoga, involved in nitrification, were recorded in Veleiros at low to medium abundance along the periphytic succession. These results indicate that denitrification and nitrogen fixation occurred in the periphyton, which has been detected by other studies [e.g.14], pointing out the important role of periphyton in eutrophication processes.

A high abundance of methanotrophs and methylotrophs, specialized bacteria capable of using methane and methanol, respectively, as a sole carbon and energy source $[39,40]$, was observed during the periphytic succession. Type I methanotrophs have been shown as the main microorganisms responsible for active methane consumption in lakes [41]. In the periphytic community of Guaíba lake, Type I methanotrophs belonging to the order Methylococcales (Gammaproteobacteria) were identified as the most abundant genera.

Among heterotrophic microeukaryotes, one of the most abundant groups found in periphytic communities are ciliates. For example, Glud and Fenchel [42] observed extreme densities of ciliates in biofilms of marine environments, with the genus Euplotes reaching $20.000 \mathrm{inds} / \mathrm{cm}^{2}$. Ackerman et al. in a long-term study of the 
periphyton from the Rhine river, observed that more than $50 \%$ of the biovolume composition of the biofilm were ciliates. In the present study, the clade Alveolata dominated the composition of the periphytic community, with ciliates reaching the highest abundance among alveolates. When the two sampling sites were compared, ciliates tended to be more diverse in Jangadeiros. This fact may be related to abiotic factors, such as water flow and temperature, or biotic factors, such as food availability and predation [44].

Several studies have focused on ciliates as a significant component of the periphyton in freshwater or marine environments $[9,10,45,46]$. Among ciliates, the most common groups found in biofilm communities are peritrichs, suctorians, and heterotrichs, since they encompass organisms that attach permanently to substrates or that could easily detach when the conditions are unfavorable. In addition, peritrich ciliates may contribute to constructing the biofilm architecture since their stalks can interconnect with filamentous bacteria forming a complex network that supports a multilayer organization of the whole community [45]. In Guaíba lake, peritrichs were the dominant ciliate taxon at both sites. In both molecular and morphological analyses, the genera Epistylis and Vorticella showed high relative abundances at the four time points. A similar result was found by Safi et al. [12] when they sampled the peritrich assemblage of Guaíba lake for one year. Epistylis and Vorticella were the most abundant and species-rich genera found in the peritrich community, clearly showing a seasonal cycle. Although Epistylis and Vorticella have been recorded as constant genera in the present study, other peritrich genera such as Opercularia and Carchesium were also abundant at specific time points. If we look at the overall diversity of peritrich taxa at both sites, Jangadeiros tended to be more diverse than Veleiros during the four time points. This difference could be related to water circulation, which is higher in Jangadeiros. At the same time, in contrast to metazoans, studies have revealed that peritrichs are highly abundant in environments that receive a considerable input of sewage $[47,48]$. Although both sites are highly polluted, slight differences in dissolved oxygen or even the type of available food (possibly driven by the differences in water current and temperature) may have led to a more diverse community found in Jangadeiros.

Ciliates are known to graze efficiently on planktonic or attached bacteria and algae. Studies of biofilms have shown that ciliates are usually the most easily recognizable grazers among the periphytic community. Specific groups of periphytic ciliates such as hypotrichs and stichotrichs could be observed dislodging attached bacteria with their cilia and collecting them with the adoral membranelles [5]. Predatory ciliates are also known to crawl upon biofilms, where they can prey on other unicellular organisms or even on metazoans [5]. In lakes saturated by organic matter, the predatory activity of ciliates releases nutrients held by a plethora of primary producers who anchor inorganic carbon inside an active microbial community [49]. On the other hand, peritrichs and heterotrichs are suspension filter feeders, consuming bacteria, algae, and other planktonic organisms present in the water column or suspended from the substrate [50]. Some genera of ciliates were abundant when specific bacterial taxa were present in the environment. Among these, we can highlight hypotrichs and oxytrichs that are probably grazing upon these bacteria, as well as some predatory ciliates that prey on unicellular eukaryotes and metazoans. Interestingly, the abundance of Epistylis and Vorticella was not correlated with the abundance of bacterial taxa, which may be related to the condition of suspension feeders of these two peritrich genera.

Overall, our results demonstrated that Guaíba lake periphyton presented a high abundance of bacteria commonly found in wastewater. Producers and denitrifiers were also part of the community, showing that biofilms can be important in nutrient recycling. Among microeukaryotes, ciliates dominated the community composed by taxa that use the periphytic community as a food source. Given the complexity of the assembled communities and the different succession processes observed at nearby sites with similar properties, we can conclude that additional 
studies focusing on the structure and dynamics of Guaíba Lake biofilms will be required to fully understand their diversity and ecological roles in this aquatic ecosystem.

\section{Declarations}

\section{Acknowledgments}

We thank High-Performance Computing Lab (LAD/PUCRS) for allowing access to run the highthroughput sequence analyses. LGAB thanks PEGA/PUCRS. We also thank Fernanda Pedone Valdez for laboratory assistance, Lucia Safi, Alex von Flebe do Amaral, and Lucas Chitolina for their help with sample collection. This work was supported by a CNPq fellowship granted to LRPU. This study was also financed in part by the Coordenação de Aperfeiçoamento de Pessoal de Nível Superior - Brasil (CAPES) - Finance Code 001.

\section{Statements and Declarations}

This work was supported by a a fellowship from CNPq (Grant number 476310/2011-3), and by a scholarship by Coordenação de Aperfeiçoamento de Pessoal de Nível Superior - Brasil (CAPES) - Finance Code 001; The authors have no relevant financial or non-financial interests to disclose; All authors contributed to the study conception and design. Material preparation, data collection and analysis were performed by Adriana Giongo, Taiz Leonor Lopes Simão, Luiz Gustavo dos Anjos Borges, Eduardo Eizirik, and Laura Roberta Pinto Utz. The first draft of the manuscript was written by Adriana Giongo and Laura Roberta Pinto Utz and all authors commented on previous versions of the manuscript. All authors read and approved the final manuscript; The datasets generated during and/or analyzed during the current study are available from the corresponding author on reasonable request; This is an observational study. The Pontifical Catholic University of Rio Grande do Sul Research Ethics Committee has confirmed that no ethical approval is required.

\section{References}

1. Wetzel RG (2001) Limnology: Lake and River Ecosystems. Academic Press

2. Wey JK, Scherwass A, Norf H, Arndt H, Weitere M (2008) Effects of protozoan grazing within river biofilms under semi-natural conditions. Aquat Microb Ecol 52:283-296

3. Vesterinen J, Devlin SP, Syvaranta J, Jones RI (2016) Accounting for littoral primary production by periphyton shifts a highly humic boreal lake towards net autotrophy. Freshwater Biol 61:265-276

4. Zeglin LH (2015) Stream microbial diversity in response to environmental changes: review and synthetic of existing research. Front Microbiol 6:454

5. Weitere M, Erken M, Majdi N, Arndt H, Norf H, Reinshagen M, Traunspurger W et al (2018) The food web perspective on aquatic biofilms. Ecol Monogr 88:543-559

6. Algarte VM, Siqueira T, Landeiro VL, Rodrigues L, Bonecker CC, Rodrigues LC, Santana NF et al (2017) Main predictors of periphyton species richness depend on adherence strategy and cell size. PLoS ONE 12:e0181720

7. Foissner W, Berger H, Kohnmann F (1992) Taxonomische und ökologische revision der ciliaten des saprobiensystems. Band II: Peritrichia, Heterotrichida, Odontostomatida. Bayerrisches Landesamt für Wasserwirtschaft, Munchen

8. Xu H, Min G-S, Choi J-K, Jung J-H, Park M-H (2009) An approach to analyses of periphytic ciliate colonization for monitoring water quality using a modified artificial substrate in Korean coastal waters. Mar Pollut Bull 
58:1278-1285

9. Mieczan T (2010) Periphytic ciliates in three shallow lakes in Eastern Poland: a comparative study between a phytoplankton-dominated lake, a phytoplankton-macrophyte lake and a macrophyte-dominated lake. Zool Stud 49:589-600

10. Sikder MNA, Al MA, Hu G, Xu H (2019) Colonization dynamics of periphytic ciliates at different water depths in coastal waters of the Yellow Sea, northern China. J Mar Biol Assoc UK 99:1065-1073

11. Lynn DH (2008) The ciliated protozoa: characterization, classification and a guide to the literature. Springer, 605 $\mathrm{pp}$

12. Safi LSL, Fontoura NF, Severo HJ, Utz LRP (2014) Temporal structure of the peritrich ciliate assemblage in a large Neotropical lake. Zool Stud 53:17

13. Singer E, Bushnell B, Coleman-Derr D, Bowman B, Bowers RM, Levy A, Gies EA et al (2016) High-resolution phylogenetic microbial community profiling. ISME J 10:2020-2032

14. Sanli K, Bengtsson-Palme J, Nilsson RH, Kristiansson E, Rosenblad MA, Blanck H, Eriksson KM (2015) Metagenomic sequencing of marine periphyton: taxonomic and functional insights into biofilm communities. Front Microbiol 6:1192

15. Cui Y, Jin L, Ko S-R, Chun SJ, Oh H-S, Lee CS, Srivastava A et al (2017) Periphyton effects on bacterial assemblages and harmful cyanobacterial blooms in a eutrophic freshwater lake: a mesocosm study. Sci Rep 7:7827

16. Groendahl S, Kahlert M, Fink P (2017) The best of both worlds: a combined approach for analyzing microalgal diversity via metabarcoding and morphology-based methods. PLoS ONE 12:e0172808

17. Kulas A, Gulin V, Kepcija RM, Zutinic P, Peric MS, Orlic S, Kajan K et al (2021) Ciliates (Alveolata, Ciliophora) as bioindicators of environmental pressure: A karstic river case. Ecol Indic 124:107430

18. Bendati MM, Schwarzbach MSR, Maizonave CRM, Almeida LB, Bringhenti ML (2003) Avaliação da qualidade da água do Lago Guaíba. Subsídios para a gestão da bacia hidrográfica. Ecos Pesquisa 7:1-34

19. Andrade LC, Tiecher T, Oliveira JS, Andreazza R, Inda AV, Camargo FAO (2018) Sediment pollution in margins of the Lake Guaíba, Southern Brazil. Environ Monit Assess 190:3

20. Scottá FC, Andrade MM, Silva VOS Jr, Oliveira N, Weschenfelder J, Bortolin EC, Nunes JC (2019) Geoacoustic patterns of the Guaíba River bottom and sub-bottom and their relationship with sedimentary and hydrodynamic processes. Bras J Geophys 37:105-120

21. Bates ST, Berg-Lyons D, Caporaso JG, Walters WA, Knight R, Fierer N (2011) Examining the global distribution of dominant archaeal populations in soil. ISME J 5:908-917

22. Nolte V, Pandey RV, Jost S, Medinger R, Ottenwälder B, Boenigk J, Schlötterer C (2010) Contrasting seasonal niche separation between rare and abundant taxa conceals the extent of protist diversity. Mol Ecol 19:29082915

23. Callahan BJ, McMurdie PJ, Rosen MJ, Han AW, Johnson AJ, Holmes SP (2016) DADA2: High-resolution sample inference from Illumina amplicon data. Nature Meth 13:581-583

24. Quast C, Pruesse E, Yilmaz P, Gerken J, Schweer T, Yarza P, Peplies J et al (2013) The SILVA ribosomal RNA gene database project: improved data processing and web-based tools. Nucleic Acids Res 41:D590-D596

25. Chen H (2021) VennDiagram: Generate High-Resolution Venn and Euler Plots. Available at: http://cran.rproject.org/ 
26. McMurdie PJ, Holmes S (2013) Phyloseq: An R package for reproducible interactive analysis and graphics of microbiome census data. PLoS ONE 8:e61217

27. Oksanen J, Blanchet FG, Friendly M, Kindt R, Legendre P, McGlinn D (2018) Vegan: Community Ecology Package. R Package Version 2.5-2. Available online at: https://CRAN.R-project.org/package=vegan

28. Lahti L et al (2017) Tools for microbiome analysis in R. Version. URL: http://microbiome.github.com/microbiome

29. Lear G, Dopheide A, Ancion P-Y, Roberts K, Washington V, Smith J, Lewis GD (2012) Biofilms in freshwater: their importance for the maintenance and monitoring of freshwater health. In: Lear G, Lewis G (eds) Microbial Biofilms Current Research and Applications. Caister Academic Press, Norfolk, pp 129-151

30. Zancarini A, Echenique-Subiabre I, Debroas D, Taib N, Quiblier C, Humbert J-F (2017) Deciphering biodiversity and interactions between bacteria and microeukaryotes within epilithic biofilms from the Loue River, France. Sci Rep 7:4344

31. Bricheux G, Morin L, Le Moal G, Coffe G, Balestrino D, Charbonnel N, Bohatier J et al (2013) Pyrosequencing assessment of prokaryotic and eukaryotic diversity in biofilm communities from a French river. MicrobiologyOpen 2:402-414

32. Levi PS, Starnawski P, Poulsen B, Baattrup-Pedersen A, Schramm A, Riis T (2017) Microbial community diversity and composition varies with habitat characteristics and biofilm function in macrophyte-rich streams. Oikos 126:398-409

33. Zhang M, Lv X, Zju W, Gao Y, Dong J, Li M, Zhang J et al (2021) The aquatic benthic food webs: The determinants of periphyton biofilms in a diversion canal and its upstream reservoir. Ecol Eng 170:106363

34. Bondar-Kunze E, Kasper V, Hein T (2021) Responses of periphyton communities to abrupt changes in water temperature and velocity, and the relevance of morphology: a mesocosms approach. Sci Total Environ 768:145200

35. Hao B, Wu H, Zhen W, Jo H, Cai Y, Jeppesen E, Li W (2020) Warming effects on periphyton community and abundance in different seasons are influenced by nutrient state and plant type: a shallow lake mesocosms study. Front Plant Sci 11:404

36. Stocker MD, Smith JE, Hernandez C, Macarisin D, Pachepsky Y (2019) Seasonality of E. coli and enterococci concentrations in creek water, sediment, and periphyton. Water Air Soil Pollut 230:223

37. Krivy P, Uthicke S (2011) Microbial diversity in marine biofilms along a water quality gradient on the Great Barrier Reef. Syst Appl Microbiol 34:116-126

38. Su J, Kang D, Xiang W, Wu C (2017) Periphyton biofilm development and its role in nutrient cycling in paddy microcosms. J Soils Sediment 17:810-819

39. Hanson RS, Hanson TE (1996) Methanotrophic Bacteria. Microbiol Rev 60:439-471

40. Chen R, Wang Y, Wei S, Wang W, Lin X (2014) Windrow composting mitigated CH4 emissions: characterization of methanogenic and methanotrophic communities in manure management. FEMS Microbiol Ecol 90:575-586

41. Crevecoeur S, Vincent WF, Comte J, Matveev A, Lovejoy C (2017) Diversity and potential activity of methanotrophs in high methane-emitting permafrost thaw ponds. PLoS ONE 12:e0188223

42. Glud RN, Fenchel T (1999) The importance of ciliates for interstitial solute transport in benthic communities. Mar Ecol Prog Ser 186:87-93

43. Ackerman B, Esser M, Scherwass A, Arndt H (2011) Long-term dynamics of microbial biofilm communities of the river Rhine with special references to ciliates. Int Rev Hydrobiol 96:1-19

Page $11 / 14$ 
44. Weisse T (2017) Functional diversity of aquatic ciliates. Eur J Protistol 61:331-358

45. Martin-Cereceda M, Álvarez AM, Serrano S, Guinea A (2001) Confocal and light microscope examination of protozoa and other microorganisms in the biofilms from a rotating biological contactor wastewater treatment plant. Acta Protozool 40:263-272

46. Vlaicevic B, Kepcija RM, Cerba D (2021) Structure and dynamics of the periphytic ciliate community under different hydrological conditions in a Danubian floodplain lake. Limnologica 87:125847

47. Small EB (1973) A study of ciliate protozoa from a small polluted stream in east-central Illinois. Am Zool $13: 225-230$

48. Kusuoka Y, Watanabe Y (1987) Growth and survival of peritrich ciliates in an urban stream. Oecologia 73:1620

49. Kirchman DL (2012) Processes in Microbial Ecology, First Edition. Oxford University Press

50. Arndt H, Schmidt-Denter K, Auer B, Weiterer M (2003) Protozoans and biofilms. In: Krumbein W, Paterson DM, Zavarzin GA (eds) Fossil and recent biofilms: A natural history of life on Earth. Springer, Dordrecht

\section{Tables}

Table 1. Sampling strategy and physical-chemical analysis of the water collected at Guaíba Lake, Brazil. Samples were collected in triplicates at four time points for each sampling site: Jangadeiros $(\mathrm{J})$ and Veleiros (V) boat piers.

\begin{tabular}{|c|c|c|c|c|c|c|c|c|}
\hline \multirow{3}{*}{$\begin{array}{l}\text { Sampling } \\
\text { site }\end{array}$} & \multirow{3}{*}{$\begin{array}{l}\text { Time- } \\
\text { based } \\
\text { sampling }\end{array}$} & \multirow{3}{*}{$\underset{\text { ID }}{\text { Sample }}$} & \multirow{3}{*}{$\begin{array}{l}\text { Days } \\
\text { after } \\
\text { starting }\end{array}$} & \multicolumn{5}{|c|}{ Water parameters } \\
\hline & & & & \multirow[t]{2}{*}{$\mathrm{pH}$} & $\begin{array}{l}\text { Total } \\
\text { solids }\end{array}$ & Conductivity & Temperature & \multirow{2}{*}{$\begin{array}{l}\text { Dissolved } \\
\mathrm{O}_{2}\left(\mathrm{mg} \mathrm{L}^{-}\right. \\
\left.{ }^{1}\right)\end{array}$} \\
\hline & & & & & $\left(\mathrm{g} \mathrm{mL}^{-1}\right)$ & $\left(\mu \mathrm{ms} \mathrm{cm^{2 }}\right)$ & $\left({ }^{\circ} \mathrm{C}\right)$ & \\
\hline \multirow[t]{4}{*}{ Jangadeiros } & $\mathrm{T} 1$ & $\mathrm{~J} 1$ & 15 & 6.1 & 0.00015 & 77 & 11 & 5.9 \\
\hline & $\mathrm{T} 2$ & $\mathrm{~J} 2$ & 20 & 6.3 & 0.000011 & 88.3 & 13.4 & 8.2 \\
\hline & T3 & J3 & 30 & 6.4 & 0.00013 & 74.7 & 14.4 & 6.9 \\
\hline & T4 & $\mathrm{J} 4$ & 55 & 6.3 & 0.015 & 83.5 & 15.4 & 7.2 \\
\hline \multirow[t]{4}{*}{ Veleiros } & $\mathrm{T} 1$ & V1 & 15 & 6.4 & 0.0002 & 82.9 & 16.9 & 6.6 \\
\hline & $\mathrm{T} 2$ & V2 & 25 & 6.6 & 0.0004 & 88.4 & 17.9 & 6.6 \\
\hline & T3 & V3 & 35 & 6.3 & 0.003 & 79.4 & 18.5 & 5.9 \\
\hline & T4 & V4 & 45 & 6.2 & 0.002 & 78 & 18 & 6 \\
\hline
\end{tabular}

\section{Figures}

\section{Figure 1}

Sampling sites at Guaíba Lake, Brazil. Samples were collected in triplicates at four time points (see Table 1) for each sampling site: Jangadeiros $(\mathrm{J})$ and Veleiros $(\mathrm{V})$ boat piers. 


\section{Figure 2}

Bacterial diversity of the periphytic communities at the two sampling sites, Jangadeiros and Veleiros boat piers, in Guaíba Lake, Brazil. Samples were collected in triplicates at four time points (see Table 1) for each sampling site. (A) Alpha diversity (Shannon diversity, Chao1 richness, and Pielou's evenness indexes) at different sampling sites and collecting time points. The dots indicate the diversity index value of each sample. Due to the rarefaction, one sample from T4 (Jangadeiros) and one from T2 (Veleiros) was not included in the analysis. Each alpha diversity index was compared between sampling sites by Kruskal-Wallis. (B) Multidimensional scaling (MDS) ordination of Bray-Curtis dissimilarity matrix by time point at the two sampling sites. Different dot colors represent time points. Venn diagram showing unique and shared bacterial taxa observed at (C) Jangadeiros and (D) Veleiros in each of the time points.

\section{Figure 3}

Relative abundance of the bacterial community composition at the two sampling sites, Jangadeiros and Veleiros boat piers, in Guaíba Lake, Brazil. Samples were collected in triplicates at four time points (see Table 1) for each sampling site. The fifty most abundant genera (or taxonomic annotation) in (A) Jangadeiros and (B) Veleiros samples are separated by time points. ANPR: Allorhizobium-Neorhizobium-Pararhizobium-Rhizobium.

\section{Figure 4}

Eukaryotic community composition at the two sampling sites, Jangadeiros and Veleiros boat piers, in Guaíba Lake, Brazil. Samples were collected in triplicates at four time points (see Table 1) for each sampling site. (A) Main eukaryotic clades; (B) Phyla within Alveolata; (C,D) Venn Diagrams showing unique and shared taxa belonging to the phylum Ciliophora found in (C) Jangadeiros and (D) Veleiros; (E) Relative abundance (square-root transformed) of Ciliophora taxa at the two sampling sites.

\section{Figure 5}

Correlation analysis between the bacterial taxa with abundance $\geq 1 \%$ and Ciliophora taxa at the two sampling sites: (A) Jangadeiros and (B) Veleiros boat piers. Spearman correlation was computed, and statistical significance was 
defined for all pairwise comparisons. Only significant correlations, either positive (blue squares) or negative (red squares) ( $p$-value <0.05), are shown.

\section{Figure 6}

Morphology-based characterization of the peritrich ciliate community present at the two sampling sites, (A) Jangadeiros and (B) Veleiros boat piers, at four time points (T1-T4; see Table 1). (C-H) Photomicrographs of the observed genera: (C) Colony of Epistylis riograndensis; (D-H) Detailed view of the zooids of: (D) Epistylis riograndensis; (E) Epistylis plicatilis; (F) Vaginicola sp.; (G) Opercularia sp.; and (H) Vorticella sp. Scale bars are 20 $\mu \mathrm{m}$.

\section{Supplementary Files}

This is a list of supplementary files associated with this preprint. Click to download.

- SupplementaryMaterial.docx 